\title{
ANALISA PEMBANGUNAN SALURAN TRANSMISI 275 kV ANTARA GI KILIRANJAO DAN GI PAYAKUMBUH
}

\author{
Irvan Buchari Tamam ${ }^{1)}$, Tony Koerniawan ${ }^{2)}$, Muhammad Nurul Ichsan ${ }^{3)}$, \\ Teknik Elektro, Sekolah Tinggi Teknik - PLN \\ 1irvanbuchari532@gmail.com \\ 2tonykoerniawan84@gmail.com \\ 3nurulichsan21.ni@gmail.com
}

\begin{abstract}
Electrical energy is very important role in human life. rapid population growth resulting in increased electricity needs in Indonesia. Based on the current state of power supply capacity of the next few years will not be able to meet the electricity demand in a number of regions in Indonesia. Therefore PLN as a provider of electrical energy as possible to meet those needs. One step is made by planning to build Transmission Line $T$ / L 275 kV substation Kiliranjao - Gl Payakumbuh. With the construction of the substation, it is also necessary distribution of electrical energy that is supplying power to a great everincreasing burden on the city through the transmission line (SUTET) $275 \mathrm{kV}$. In this study will discuss the environmental feasibility study of development of the transmission line $T$ / L 275 kV Kiliranjao - Payakumbuh and substation. Environmental feasibility study is to obtain accurate information in anticipation of environmental problems that arise and will occur as a result of the construction of the transmission $T / L 275 \mathrm{kV}$, which is useful for various parties, such as PT. PLN as the initiator, the Local Government and Communities.
\end{abstract}

Keywords: Transmission $T / L 275$ kV, electric energy, electric field

Abstrak : Energi listrik sangat penting peranannya dalam kehidupan manusia. pertumbuhan penduduk yang pesat mengakibatkan meningkatnya kebutuhan energi listrik di Indonesia. Berdasarkan kondisi saat ini kapasitas pasokan tenaga listrik beberapa tahun mendatang tidak akan dapat memenuhi permintaan tenaga listrik di sejumlah wilayah di Indonesia. Oleh karena itu PLN sebagai penyedia energi listrik semaksimal mungkin untuk memenuhi kebutuhan tersebut. Salah satu langkah yang dilakukan yaitu dengan merencanakan membangun Saluran Transmisi T/L 275 kV GI Kiliranjao - Gl Payakumbuh. Dengan adanya pembangunan Gardu Induk tersebut, perlu juga dilakukan penyaluran energi listrik yaitu mensuplai daya yang besar untuk beban yang semakin bertambah di kota tersebut melalui saluran transmisi (SUTET) $275 \mathrm{kV}$. Dalam penelitian ini akan membahas tentang studi kelayakan lingkungan pembangunan saluran transmisi T/L 275 kV Kiliranjao - Payakumbuh dan Gardu Induk. Studi kelayakan lingkungan ini untuk memperoleh informasi yang akurat dalam mengantisipasi permasalahan lingkungan yang timbul dan akan terjadi sebagai dampak dari pembangunan transmisi $T / L 275 \mathrm{kV}$ ini, yang berguna bagi berbagai pihak, seperti $P T$. PLN selaku pemrakarsa, Pemerintah Daerah dan Masyarakat.

Kata Kunci : Transmisi T/L 275 kV, energi listrik, medan listrik

\section{PENDAHULUAN}

Peningkatan kapasitas listrik sampai saat ini masih sangat terbatas. Berbagai wilayah yang mengalami krisis listrik diperkirakan akan terus berlanjut. Namun ke depan khususnya di luar Jawa terdapat sebagian kecil daerah yang krisis listriknya relatif akan mengalami perbaikan sekalipun belum dapat pulih menjadi sistem yang handal dan mampu menyediakan listrik sepenuhnya termasuk memenuhi pertumbuhan permintaan yang secara memadai. 
Selanjutnya dalam RUPTL 20072016 dinyatakan bahwa meningkatkan keandalan sebagai penyaluran energi listrik, perluasan jaringan dan pemerataan kelistrikan pada beberapa daerah di wilayah Sumatera perlu diwujudkan Interkoneksi Sistem Sumatera pada tahun 2009 dan dilanjutkan sistem JawaSumatera pada tahun 2010. Pada sisi lain, ditinjau dari sektor pelayanan dinyatakan target rasio elektrifikasi sekitar $70 \%$ dan rasio desa berlistrik sekitar $90 \%$ dengan 44 juta pelanggan pada tahun 2010.

Pembangunan Jaringan Transmisi T/L 275 kV Kiliranjao - Payakumbuh sepanjang 125 km dan Gardu Induk (GI) terkait pada dasarnya merupakan kebijakan Pemerintah dalam upaya memenuhi kebutuhan listrik di Sumatera pada umumnya dan Sumatera Selatan, Jambi, Lampung, Bangka Belitung dan Sumatera Barat pada khususnya. Berdasarkan proyeksi kebutuhan listrik di luar Jawa termasuk daerah Sumatera Selatan, Jambi, Lampung, Bangka Belitung dan Sumatera Barat terdapat kecenderungan peningkatan penjualan energi dari ahun 2006 sampai 2010 berkisar antara $3,1-8,1 \%$.

Tujuan dan manfaat penelitian ini adalah untuk membahas tentang studi kelayakan lingkungan pembangunan saluran transmisi T/L 275 kV Kiliranjao Payakumbuh dan Gardu Induk. Studi kelayakan lingkungan ini untuk memperoleh informasi yang akurat dalam mengantisipasi permasalahan lingkungan yang timbul dan akan terjadi sebagai dampak dari pembangunan transmisi $\mathrm{T} / \mathrm{L}$ 275 kV ini, yang berguna bagi berbagai pihak, seperti PT. PLN selaku pemrakarsa, Pemerintaah Daerah dan Masyarakat.

\section{LANDASAN TEORI}

Tenaga listrik dapat dibangkitkan dengan mudah dan ekonomis hanya pada tempat-tempat dimana sumber dari pembangkit tenaga seperti batubara dan air tersedia. Ini jelas bahwa sumber dari tenaga listrik tersebut tidak tersedia pada seluruh tempat, karena itu lokasi pembangkit dibangun pada tempat yang benar-benar tersedia kebutuhankebutuhan untuk pembangkitan itu sendiri. Dan melalui saluran transmisi inilah penyaluran tenaga listrik ini sampai pada konsumen. Adapun komponen komponen utama dari saluran transmisi terdiri dari menara transmisi atau tiang transmisi beserta pondasinya, isolator isolator, kawat penghantar (conductor), dan kawat tanah (ground wire).

\subsection{Medan Magnet dan Medan Listrik}

Medan magnet, dalam ilmu Fisika, adalah suatu medan yang dibentuk dengan menggerakan muatan listrik (arus listrik) yang menyebabkan munculnya gaya di muatan listrik yang bergerak lainnya. (Putaran mekanika kuantum dari satu partikel membentuk medan magnet dan putaran itu dipengaruhi oleh dirinya sendiri seperti arus listrik; inilah yang menyebabkan medan magnet dari ferromagnet "permanen"). Sebuah medan magnet adalah medan vector, yaitu berhubungan dengan setiap titik dalam ruang vektor yang dapat berubah menurut waktu. Arah dari medan ini adalah seimbang dengan arah jarum kompas yang diletakkan di dalam medan tersebut.

Medan listrik adalah daerah di sekitar benda bermuatan listrik yang masih mengalami gaya listrik. Medan listrik adalah gaya listrik persatuan muatan. Karena gaya listrik mengikuti prinsip superposisi secara vektor, demikian juga yang terjadi pada medan listrik. Hal ini berarti kuat medan listrik dari beberapa muatan titik adalah jumlah vektor kuat medan listrik dari masing-masing muatan titik. Sehingga kuat medan listrik dari beberapa muatan titik adalah jumlah vektor kuat medan listrik dari masingmasing muatan titik. Suatu titik dikatakan berada dalam medan listrik apabila suatu benda yang bermuatan listrik ditempatkan pada titik tersebut akan mengalami gaya listrik.

\subsection{Sumber Medan Listrik Dan Medan Magnet}

Medan listrik dan Medan magnet telah ada sejak bumi dan alam semesta ini diciptakan. Atmosfir yang menyelimuti bumi mempunyai lapisan ionosfir yang 
menimbulkan Medan listrik alam. Medan listrik ini pada cuaca cerah berkisar antara $0,1 \mathrm{~s} / \mathrm{d} \quad 0,5 \mathrm{kV} / \mathrm{m}$ dan pada saat awan mendung berkisar antara $3 \mathrm{~s} / \mathrm{d} 30 \mathrm{kV} / \mathrm{m}$. Medan listrik yang diakibatkan oleh awan merupakan dimana kondisi atmosfer bumi tertentu seperti suhu, tekanan udara dan kelembaban yang tinggi akan menyebabkan awan badai terbentuk.

Medan listrik dan medan magnet buatan manusia yaitu seperti pada kawat penghantar SUTT/SUTET yang bertegangan akan timbul medan listrik, dan apabila pada kawat penghantar tersebut mengalir arus listrik maka disamping medan listrik juga akan dibangkitkan medan magnet. Sebagai contoh lain, medan listrik juga akan timbul pada kabel lampu meja yang tersambung ke stop kontak, dan pada saat lampu dinyalakan (ada arus mengalir pada kabel), maka disamping medan listrik juga timbul Medan magnet.

Medan listrik juga dapat ditimbulkan oleh beberapa dari peralatan listrik yang sering digunakan dalam kegiatan seharihari, dan berikut beberapa peralatan listrik yang menimbulkan medan listrik seperti yang ditunjukkan pada tabel di bawah ini.

Tabel 2.1 Medan listrik pada beberapa peralatan listrik

\begin{tabular}{|c|c|}
\hline PERALATAN & MEDAN USTRIK(VOLT/METER) \\
\hline Selimut Listrik & 250 \\
\hline Stereo Set & 90 \\
\hline Lemari Pendingin & 60 \\
\hline Setrika Listrik & 60 \\
\hline Pengering Rambut & 40 \\
\hline TV Berwarna & 30 \\
Penyedot Debu & 16 \\
\hline Lampu Pijar & 2 \\
\hline
\end{tabular}

Tabel 2.2 Medan magnet pada beberapa peralatan listrik

\begin{tabular}{|c|c|c|c|}
\hline PFRAI ATAl & \multicolumn{3}{|c|}{ MEDANMAGNET $(\mu \mathrm{T})$} \\
\hline & $3 \mathrm{~cm}$ & $30 \mathrm{~cm}$ & $100 \mathrm{~cm}$ \\
\hline Pengering rambut & $6-2000$ & $0,01-7$ & $0,01-0,3$ \\
\hline Alat cukur & $15-1500$ & $0,08-5$ & $0,01-0,3$ \\
\hline Bor listrik & $4000-800$ & $2-3,5$ & $0,08-0,2$ \\
\hline Mixer & $60-700$ & $0,6-10$ & $0,02-0,025$ \\
\hline Televisi & $2,5-50$ & $0,04-2$ & $0,01-0,15$ \\
\hline Setrika listrik & $8-30$ & $0,12-0,3$ & $0,01-0,025$ \\
\hline Lemari pendingin & $0,5-1,7$ & $0,01-0,25$ & $<0.01$ \\
\hline
\end{tabular}

\subsection{Dampak Pembangunan SUTET di Indonesia}

a. Sosial Masyarakat

Terjadinya keresahan dan ketakutan yang disebabkan dari munculnya rasa tidak aman terhadap bahaya kecelakaan yang dapat ditimbulkan dari jaringan tersebut yaitu kecelakaan yang dapat ditimbulkan dari jaringan tersebut yaitu kecelakaan yang disebabkan adanya sambaran petir, putusnya kabel atau gangguan fondasi menara akibat perubahan struktur tanah sehingga menimbulkan masalah terkait pembebasan lahan dan pemindahan penduduk ke area di luar jalur SUTET. Selain itu munculnya kekhawatiran kesehatan secara terus menerus yang disebabkan oleh radiasi gelombang elektromagnetik.

\section{b. Ekonomi}

Secara makro mungkin pembangunan SUTET berimplikasi pada kesejahteraan rakyat karena mampu meningkatkan aktivitas industri di Indonesia sehingga GDP meningkat. Namun di satu sisi pembangunan jaringan tegangan tinggi tersebut dapat menyebabkan "Kematian Perdata" bagi nilai tanah yang di lintasi SUTET, sehingga apabila pemilik tanah berniat menjual tanahnya, maka harga jual tanah tersebut akan jatuh dan berada di bawah harga jual yang tidak dilewati jalur tersebut (itupun bila ada yang mau membelinya), atau juga pemilik tanah mau mengoptimalisasi tanahnya dengan mendirikan bangunan bertingkat ia akan mempunyai masalah dengan perijinan pendirian bangunan, atau bila ia ingin menanam pohon ia akan dilarang menanam dalam batas ketinggian tertentu.

\section{c. Kesehatan}

WHO berkesimpulan bahwa tidak banyak pengaruh yang ditimbulkan oleh medan listrik sampai $20 \mathrm{kV} / \mathrm{m}$ pada manusia dan medan listrik sampai 100 $\mathrm{kV} / \mathrm{m}$ tidak memengaruhi kesehatan hewan percobaan. Selain itu, percobaan beberapa sukarelawan pada medan magnet $5 \mathrm{mT}$ hanya memiliki sedikit efek pada hasil uji klinis dan fisik. 
d. Budaya

Menciptakan budaya self-injury (menyakiti diri sendiri) dikalangan masyarakat akibat hak-hak para korban SUTET belum terpenuhi. Beberapa aksi self-injury yang dilakukan masyarakat pada tanggal 30 Januari 2006, yaitu: aksi jahit mulut, mogok makan, dan cap jempol darah yang berlangsung di Posko Selamatkan Rakyat Indonesia di Jalan Diponegoro - Jakarta Pusat. Puluhan orang sudah melakukan aksi tersebut dan sudah berjatuhan korban dari aksi tersebut, bahkan ibu-ibu rela meninggalkan keluarga dan anak-anak mereka tercinta demi melakukan aksi tersebut.

\section{METODE PENELITIAN}

\subsection{Standar Ambang Batas Medan Listrik}

Berdasarkan SPLN-112-1994 pada

Pasal 3 mengenai ambang batas kuat medan listrik dan induksi medan magnet untuk melindungi manusia bahwa ambang batas nilai efektif kuat medan listrik (Eb) secara terus menerus adalah $\mathrm{Eb}=10$ $\mathrm{kV} / \mathrm{m}$. Diukur/dihitung pada ketinggian 1 meter di atas permukaan tanah pada medan yang tidak terganggu. Serta ambang batas nilai efektif induksi medan magnet (Bb) secara terus menerus adalah $\mathrm{Bb}=0,5 \mathrm{mT}$. Diukur/dihitung pada ketinggian $1 \mathrm{~m}$ di atas tanah pada medan yang tidak terganggu.

Badan Standarisasi Nasional Indonesia tentang Saluran Udara Tegangan Tinggi (SUTT) dan Saluran Udara Tegangan Ekstra Tinggi (SUTET). Nilai Ambang Batas Medan Listrik dan Medan Magnet. Standar ini berlaku sebagai pedoman untuk menetapkan ruang batas dan jarak bebas minimum pada Saluran Udara Tegangan Tinggi (SUTT) dan Saluran Udara Tegangan EkstraTinggi (SUTET). Standar ini berlaku untuk SUTT dengan tegangan nominal $66 \mathrm{kV}$ dan 150 kV serta SUTET dengan tegangan nominal $275 \mathrm{kV}$ dan $500 \mathrm{kV}$ di Indonesia, baik dengan menggunakan menara baja maupun tiang baja/beton.
Tabel 3.1 Ambang Batas Pemaparan Medan Listrik dan Medan Magnet 50/60 Hz

\begin{tabular}{|c|c|c|}
\hline Karakteristik pemaparan & $\begin{array}{c}\text { Kuat modan listrik } \\
\mathrm{kV} / \mathrm{m} \\
\text { (efektif) }\end{array}$ & $\begin{array}{c}\text { Kuat modan magnit } \\
\text { (korapatan fluks } \\
\text { magnet) } \\
\text { mT } \\
\text { (efoktif) } \\
\end{array}$ \\
\hline $\begin{array}{l}\text { Yang berhubungan } \\
\text { dengan pekeriaan } \\
\text { Seluruh harl kerja } \\
\text { Jangka pendek } \\
\text { Hanya pada lengan } \\
\text { Yang berhubungan dengan } \\
\text { masyarakat umum } \\
\text { Sampai dengan } 24 \text { jam/harl } \\
\text { Beberapa jam/hari }\end{array}$ & $\begin{array}{c}10 \\
30^{2} \\
\end{array}$ & $\begin{array}{l}0,5 \\
5^{6} \\
25\end{array}$ \\
\hline
\end{tabular}

WHO pada tahun 1990 memberikan rekomendasi untuk nilai ambang batas medan listrik seperti terlihat pada tabel 3.2 berikut:

\begin{tabular}{|c|c|c|}
\hline Karakteristik pemaparan & $\begin{array}{c}\text { Kuat } \\
\substack{\text { medan lisurik } \\
\text { (efektif) }}\end{array}$ & $\begin{array}{c}\text { Kuat medan magnit } \\
\text { (kerapatan fluks } \\
\text { magnet) } \\
\mathrm{mT} \\
\text { (efextif) } \\
\end{array}$ \\
\hline $\begin{array}{l}\frac{\text { Yang berhubungan }}{\text { dengaan pekeriaan }} \\
\text { Seluruh hari kerja } \\
\text { Jangka pendek } \\
\text { Hanya pada lengan } \\
\text { Yang berhubungan dengan } \\
\text { masyarakat umum } \\
\text { Sampai dengan } 24 \text { jam/harle } \\
\text { Beberapa jam/hari }\end{array}$ & $\begin{array}{l}10 \\
30^{\circ} \\
-\end{array}$ & $\begin{array}{l}0,5 \\
5^{5} \\
25\end{array}$ \\
\hline $\begin{array}{l}\text { Durasi permaparan medar } \\
\text { 80/E, dengan } \mathrm{t} \text { adalah duras } \\
\text { listrik dalam } \mathrm{KVh} \text {. } \\
\text { b Durasi pemaparan maksi } \\
\text { Pembatasan ini berlaku } \\
\text { umum dapat secara wajar } \\
\text { selama satu hari, seperti mis } \\
\text { lain-lain yang semacam itu. } \\
\text { o Nilai kuat medan listrik } \\
\text { beberapa menithari asalkan } \\
\text { kopling tak langsung. }\end{array}$ & $\begin{array}{l}\operatorname{tara} 10 \text { dan } 30 \mathrm{kV} / \mathrm{m} \text { dz } \\
\text { lam jam per hari kerja } \\
\text { nadalah } 2 \text { jam per hari } \\
\text { uk ruang lerbuka di } \\
\text { erkirakan menghabisk } \\
\text { a kawasan rekreasi, la } \\
\text { kuat medan magnet da } \\
\text { mbil tindakan pencega }\end{array}$ & $\begin{array}{l}\text { th dihitung dari rumus } t \\
\text { in } \mathrm{E} \text { adaiah kuat medar } \\
\text { rija. } \\
\text { na anggota masyaraka } \\
\text { sebagian besar wakt. } \\
\text { ngan untuk bertemu dar } \\
\text { it dilampaui untuk duras } \\
\text { in untuk mencegah efek }\end{array}$ \\
\hline
\end{tabular}

Tabel 3.2 Nilai Ambang Batas Medan Listrik Berdasarkan Rekomendasi WHO 1990

\begin{tabular}{|c|c|}
\hline $\begin{array}{c}\text { Intensitas Medan Listrik } \\
(\mathrm{kV} / \mathrm{m})\end{array}$ & $\begin{array}{c}\text { Lama Exposure per 24 } \\
\text { jam yang diperbolehkan } \\
\text { (menit) }\end{array}$ \\
\hline 5 & Tidak Terbatas \\
\hline 10 & 180 \\
\hline 15 & 90 \\
\hline 20 & 10 \\
\hline 25 & 5 \\
\hline
\end{tabular}

Berdasarkan SPLN-112-1994

Bagi masyarakat umum, WHO 1990 merekomendasikan tingkat pemaparan maksimum adalah $5 \mathrm{kV} / \mathrm{m}$ untuk medan listrik. 


\subsection{Penilaian Kondisi Lingkungan}

Menurut

Peraturan

Menteri

Lingkungan Hidup Republik Indonesia Nomor 5 Tahun 2012 Tentang Rencana Usaha atau Kegiatan yang wajib memiliki Analisis Mengenai Dampak Lingkungan, pada pembangunan jaringan transmisi Saluran Udara Tegangan Tinggi $>150 \mathrm{kV}$ aspek yang harus ditinjau adalah :

a. Keresahan masyarakat karena pembebasan tanah, bangunan dan tanaman.

b. Adanya medan magnet dan medan listrik.

c. Aspek fisik-kimia, biologi, sosial, ekonomi dan budaya terutama pada pembebasan lahan dan keresahan masyarakat.

Dari semua aspek tersebut akan dinilai berdasarkan skala 1 sampai 5 . Setelah semua aspek dinilai berdasarkan skala tersebut maka akan disimpulkan bahwa pembangunan jaringan transmisi 275 kV Kiliranjao - Payakumbuh ini layak atau tidak layak jika ditinjau dari segi dampak lingkungan.

Skala 1 = Sangat Buruk

Skala 2 = Buruk

Skala 3 = Sedang

Skala $4=$ Baik

Skala 5 = Sangat Baik

\section{HASIL DAN PEMBAHASAN}

Berdasarkan hasil survei, jumlah menara yang akan dibangun sebanyak 367 menara. Menara tersebut terdiri dari dua tipe, yaitu menara lurus (AA) dan menara sudut (BB, CC dan DD). Jarak antar menara (SPAN) bervariasi dan sangat tergantung pada kondisi topografis wilayah. Jarak terpendek antar menara 127, 398 m pada Menara 132 - 133 (T 132 - 133) di Desa Pandan Tanjung Gadang, Kabupaten Sijunjung. Panjang jalur lintasan transmisi secara keseluruhan dari Kiliranjao - Payakumbuh $124.623,769 \mathrm{~m}$ atau $\pm 125 \mathrm{~km}$.

Di samping pembangunan jaringan transmisi T/L 275 kV Kiliranjao Payakumbuh, juga dilengkapi dengan pembangunan Gardu Induk (Gl) 275 kV pada lokasi Kiliranjao dan Payakumbuh tersebut. Lokasi GI 275 kV yang akan dibangun tersebut terletak berdampingan dengan GI 150 kV yang ada saat ini untuk memudahkan Sistem Penyaluran Energi Listrik (SPEL). Luas masing-masing $\mathrm{Gl}$ diperkirakan $2 \mathrm{Ha}$.

\subsection{Perkiraan Kuat Medan Listrik Pada \\ Saluran Transmisi T/L 275 kV Kiliranjao - Payakumbuh \\ Sebelum dapat menghitung kuat} medan listrik di bawah saluran transmisi pada T/L 275 kV Kiliranjao Payakumbuh, perlu diketahui terlebih dahulu beberapa informasi antara lain.

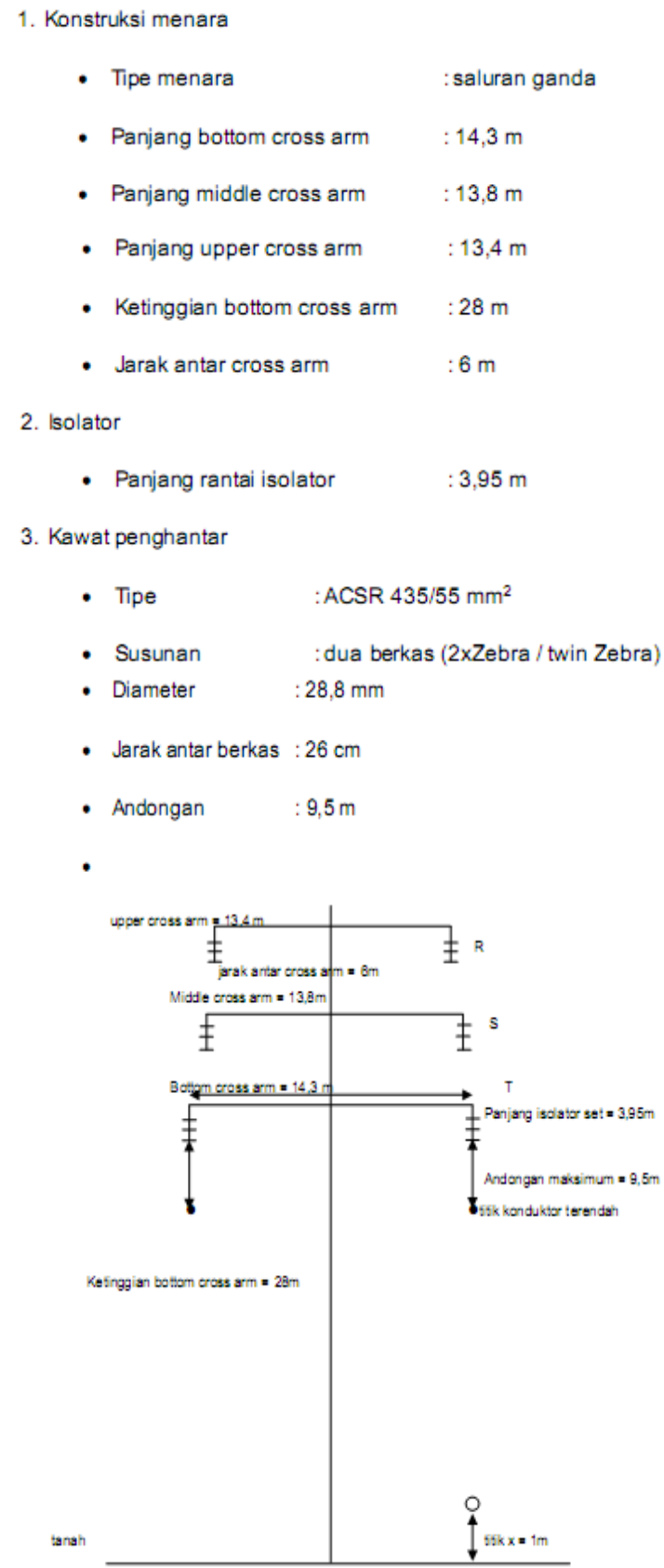

Gambar 4.1 Perhitungan Medan Listrik di bawah Saluran Transmisi 275 kV Kiliranjao Payakumbuh 
Berdasarkan informasi yang diperoleh diatas, maka nilai-nilai variabel yang terdapat pada gambar adalah :

$\begin{array}{ll}\mathrm{PI} & =3,95 \mathrm{~m} \\ \mathrm{Dmax} & =9,5 \mathrm{~m} \\ \mathrm{H} & =28 \mathrm{~m} \\ \text { Rkonduktor } & =14,4 \mathrm{~mm} \\ \mathrm{rab} & =26 \mathrm{~cm} \\ \mathrm{~V} 21 & =275 \mathrm{kV}\end{array}$

Kuat medan listrik dapat dicari menggunakan persamaan :

$$
E x=\frac{V_{21}}{X \ln \frac{r 2}{r 1}}
$$

Dikarenakan saluran ini terdiri dari 2 berkas, maka mencari $r$ ekuivalen (req) menggunakan persamaan :

$$
\begin{aligned}
& r_{e q}=\left[r \cdot n\left(r_{a b}\right)^{n-1}\right]^{1 / n} \\
& r_{e q}=\left[0,0144 \times 2(0,26)^{2-1}\right]^{1 / 2} \\
& r_{e a}=0,0865 \mathrm{~m}
\end{aligned}
$$

Jarak titik terendah konduktor terhadap titik $\mathrm{x}(\mathrm{X})$ adalah :

$$
\begin{aligned}
& X=h-\left(P_{\text {isolator }}+D_{\max }+1 m\right) \\
& X=28 m-(3,95 m+9,5 m+1 m) \\
& X=13,55 m
\end{aligned}
$$

Jadi jarak konduktor terhadap tanah (r2) adalah :

$$
\begin{aligned}
& r 2=h-\left(P_{\text {isolator }}+D_{\max }\right) \\
& r 2=28 m-(3,95 m+9,5 m) \\
& r 2=14,55 m
\end{aligned}
$$

Maka kuat medan listrik nya adalah :

$$
\begin{aligned}
& E x=\frac{V_{21}}{X \ln \frac{r 2}{r_{e q}}} \\
& E x=\frac{275 \mathrm{kV}}{13,55 \ln \frac{14,55}{0,0865}} \\
& E x=3,959 \mathrm{kV} / \mathrm{m}
\end{aligned}
$$

Untuk mengetahui berapa kuat medan listrik jika ketinggian titik uji di tambah maka dapat di lihat pada tabel berikut :
Tabel 4.1 Kuat Medan Listrik Pada Saluran Transmisi $275 \mathrm{kV}$

\begin{tabular}{|l|c|c|c|}
\hline $\begin{array}{c}\text { Ketinggian titik } \\
\text { uji }\end{array}$ & $\mathrm{X}$ & $\mathrm{r} 2$ & Ex \\
\hline 1 meter & $13,55 \mathrm{~m}$ & $14,55 \mathrm{~m}$ & $3,959 \mathrm{kV} / \mathrm{m}$ \\
\hline 2 meter & $12,55 \mathrm{~m}$ & $14,55 \mathrm{~m}$ & $4,275 \mathrm{kV} / \mathrm{m}$ \\
\hline 3 meter & $11,55 \mathrm{~m}$ & $14,55 \mathrm{~m}$ & $4,645 \mathrm{kV} / \mathrm{m}$ \\
\hline 4 meter & $10,55 \mathrm{~m}$ & $14,55 \mathrm{~m}$ & $5,085 \mathrm{kV} / \mathrm{m}$ \\
\hline 5 meter & $9,55 \mathrm{~m}$ & $14,55 \mathrm{~m}$ & $5,618 \mathrm{kV} / \mathrm{m}$ \\
\hline
\end{tabular}

Selain dipengaruhi oleh ketinggian titik uji, kuat medan listrik di bawah saluran transmisi juga di pengaruhi oleh posisi titik uji. Berdasarkan SNI 04-69502003, batas medan listrik maksimum selama 24 jam/hari untuk masyarakat umum adalah sebesar $5 \mathrm{kV} / \mathrm{m}$. Nilai ini akan terlewati pada ketinggian titik uji 4 meter. Oleh karena itu, batas batas ketinggian maksimum dibawah saluran transmisi $275 \mathrm{kV}$ adalah $<4 \mathrm{~m}$, misalkan ditentukan $3 \mathrm{~m}$. Artinya, jika dibawah saluran transmisi terdapat tumbuhtumbuhan atau perkebunan maka ketinggiannya tidak boleh lebih dari $3 \mathrm{~m}$.

Dari nilai batas ketinggian maksimum ini, dapat dihitung ruang bebas (clearance) vertikal dari saluran transmisi. Caranya adalah:

Ketinggian bottom cross arm $=28 \mathrm{~m}$

Panjang rantai isolator $=3,95 \mathrm{~m}$

Andongan maksimum $=9,5 \mathrm{~m}$

Maka jarak konduktor terdekat ke permukaan bumi adalah:

$$
h=28-3,95-9,5=14,55 m
$$

Jika batas ketinggian maksimum ditetapkan adalah $3 \mathrm{~m}$, maka ruang bebas vertikal dari saluran transmisi $275 \mathrm{kV}$ ini adalah:

$$
\mathrm{C}=\mathrm{h}-3=14,55-3=11,55 \mathrm{~m}
$$

\subsection{Aspek Fisik-Kimia, Biologi, dan Sosekbudkesmas}

Secara umum kualitas lingkungan pada jalur pembangunan jaringan transmisi T/L 275 kV KiliranjaoPayakumbuh adalah tergolong sedangbaik (skala 3-4) yang dilihat dari nilai keragaman pohon yang terdapat pada keempat lokasi pengamatan.

Berdasarkan hasil responden pada masyarakat terkenan dampak menunjukkan bahwa responden setuju, yang ragu- 
ragu dan tidak setuju. Mengenai ganti rugi tanah atau lahan yang terpakai menurut responden hendaknya diadakan musyawarah atau dibentuk panitia khusus yang mengurus hal tersebut dan harga ganti rugi hendaknya sesuai dengan nilai jual obyek pajak (NJOP), agar masyarakat tidak merasa dirugikan.

\subsection{Kelayakan Lingkungan}

Rekomendasi untuk kelayakan lingkungan hidup kegiatan pembangunan jaringan transmisi T/L 275 kV Kiliranjao Payakumbuh dan pembangunan GI mengacu pada analisis dampak terhadap komponen lingkungan hidup yang diperkirakan akan muncul. Berdasarkan dampak penting terdapat parameter lingkungan hidup yang terkena dampak negatif yaitu :

a. Keresahan masyarakat,

b. Erosi tanah / longsor,

c. Pola penggunaan lahan,

d. Keanekaragaman flora,

e. Kesehatan masyarakat, dan

f. Gangguan lalu lintas.

Dampak yang ditimbulkan oleh kegiatan pembangunan Jaringan Transmisi T/L 275 kV Kiliranjao - Payakumbuh baik tahap pra konstruksi, konstruksi dan pasca konstruksi terhadap komponen lingkungan hidup fisik-kimia, biologi dan sosekbudkesmas yang mungkin terkena dampak masih dapat dilakukan upaya pengelolaan dan pemantauan lingkungan hidup melalui pendekatan teknologi, sosial dan institusi yang ada dan tersedia saat ini. Kegiatan pembangunan Jaringan Transmisi T/L 275 kV Kiliranjao Payakumbuh ini dapat di rekomendasikan layak secara lingkungan.

\section{KESIMPULAN}

1. Besar kuat medan listrik pada saluran transmisi 275 kV Kiliranjao Payakumbuh diperkirakan melewati ambang batas yang ditetapkan SNI 04-6950-2003 dan WHO $(5 \mathrm{kV} / \mathrm{m})$ pada ketinggian titi uji sebesar 4 meter, dengan kuat medan listrik sebesar $5,085 \mathrm{kV} / \mathrm{m}$.

2. Jarak ruang bebas vertikal dari saluran transmisi $275 \mathrm{kV}$ Kiliranjao Payakumbuh sebesar 11,55 meter.

3. Setelah ditinjau dari semua aspek yang ditetapkan oleh Peraturan Menteri Lingkungan Hidup Republik Indonesia Nomor 5 Tahun 2012, pembangunan Saluran Transmisi 275 kV Kiliranjao - Payakumbuh direkomendasikan layak secara lingkungan.

\section{REFERENSI}

1. Arismunandar, Artono. (2004). "Buku pegangan teknik tenaga listrik jilid II". Jakarta: Pradnya Paramita.

2. Hutauruk, T.S. (1985). "Transmisi daya listrik". Jakarta: Erlangga.

3. Hardika, Irwan. (2009). "Pengaruh konfigurasi saluran transmisi $500 \mathrm{kV}$ dengan sirkit ganda terhadap kuat medan listrik".

4. Prasetyo, Irwan. (2004). "Kuat medan listrik sebelum pengoperasian saluran transmisi 150 kV Perean-Ubud".

5. PT. PLN (Persero) UIP II Jaringan Sumatera. "Analisa Mengenai Dampak Lingkungan Jaringan Transmisi 275 kV KiliranjaoPayakumbuh.

6. SNI 04-6950-2003. "Saluran Udara Tegangan Tinggi (SUTT) dan Saluran Udara Tegangan Ekstra Tinggi (SUTET)".

7. SPLN-112-1994. "Ambang Batas Kuat Medan Listrik dan Induksi Medang Magnet pada SUTT dan SUTET. 